\title{
MJN LEVEL OF CRITICAL THINKING ABILITY AMONG NURSING STUDENTS
}

\author{
Lim Swee Geok*, Lau Mei Yee, Ho Ai Lian \\ International Medical University, Kuala Lumpur, Malaysia \\ *Corresponding Author's Email: sweegeok_lim@imu.edu.my
}

\begin{abstract}
Introduction: Critical thinking is an important element in nursing practice as well as being a vital educational outcome in any nursing curriculum. Critical thinking can influence the outcome of patient care and patient satisfaction. Objective: To determine the level of critical thinking ability among nursing students in two nursing colleges and its differences according to social demographic variables. Method: This was a cross sectional descriptive study design in which Critical Ability Scale for College Students were used to collect data from 158 nursing students in two private nursing colleges in Malaysia. Participants were recruited through convenience sampling. Results: The mean overall score for critical thinking ability was $70.6 \pm 6.98$ with scores ranging from 56 to 89 . The mean score of the subscales was $3.63 \pm 0.50$ for intellectual, eagerness and health skepticism abilities, $3.63 \pm 0.42$ for intellectual honesty ability, $3.61 \pm 0.41$ for prudence ability and $2.68 \pm 0.64$ for objectivity ability. There are no significant differences between the independent variables and level of critical thinking ability. Conclusion: A high critical thinking ability score was reported with intellectual, eagerness and health skepticism being the highest subscale. The way forward requires academicians and clinicians to work together to ensure a transfer of knowledge and skills from the classroom to the clinical environment in order to develop and enhance the ability to think critically in making clinical decision and produce thinking nurses for the future.
\end{abstract}

Keywords: Critical Thinking, Critical Thinking Ability, Nursing Students

\section{INTRODUCTION}

Critical thinking ability is related to the learning process through knowledge, which consist of daily social cognitive, behavioural, education activities, employee training, contemporary health care programme, structure and previous nursing students' experience (Aliakbari et al., 2015). Critical thinking ability is a significant competency in nursing profession. It is a highly recognised expected outcome for student nurses or qualified nurses to earn critical thinking skills in contemporary society. The concept of critical thinking in nursing is mainly focused on cognitive and reasoning processes. According to Selen \& Filiz (2015), critical thinking is the key element of nursing practice, because critical thinking constitutes the base of developing accurate communication. As critical thinking influence patient care potentially, it is deemed very important. The interest to look into critical thinking level and ability among nurses is due to the nature of work as well as the challenges from global and local factors to ensure that a safe and quality patient care is being delivered. As today's society is developing and changing very rapidly especially in healthcare, it is very important that a teaching and learning climate provides adequate opportunities for learners to engage in activities that requires them to develop the ability to think critically instead of rote learning. Hence, the ability to think critically is a desired outcome across the educational spectrum and a common goal that most nursing educators aspire to achieve.

In an evidence-based century, the ability to master nursing practice through the nursing body of knowledge is required in making effective clinical reasoning and decision making resulting in providing optimal patient care. Nurses are expected to make effective decisions and carry out nursing interventions, geared towards health care demands and expectations in their daily patient care and medical emergencies. Nursing students gain learning habits from their learning experiences prior to entering nursing school. Many studies had emphasized the need to pay high priority to critical thinking skills in their nursing curricula (Jackson, 2016; 
Hunter et al., 2014). Rezaeil et al., (2015) reported that the level of critical thinking among Malaysian nursing students is low. According to $\mathrm{Ng}$ (2015) this could be contributed to failure to relate theory to practice. Students practice memorisation concept in nursing care, procedures and care plans without complex thinking. In contrast, critical thinking requires an active thinking process, reading, understanding, selecting and assessing complex and non - critical issues daily before taking any actions to ensure best patient outcome. This can be achieved when a nursing college or university have proper internship programme to allow better clinical posting and experience for student nurses. In fact, all types of medical-clinical practice have taken a major portion of formal health care education programme. According to Da Silva \& Krishnamurthy (2016), a lack of emphasis on critical thinking among health care personnel, resulted in medication errors on patients and incurred economic impact to their hospital.

According to the Ministry of Higher Education Malaysia (2010), the nursing core competency consist of critical thinking and the application of knowledge into clinical practice that require an extended education as a basic liberal foundation that will differentiate a professional nurse from a technical nurse. Thus, the Nursing Board Malaysia, had proposed an outcomebased education (OBE) to be incorporated into the Nursing curriculum. This will include critical thinking, application of intellectual knowledge to practice focus, problem solving, communication and leadership skills. Clinical knowledge, competence and performance will also be assessed.

According to Song et al., (2014), the scores of critical thinking ability are low. Only a small number of nurses achieved high level of critical thinking because some of the nursing colleges still adopt conservative mode of teaching, which is spoon feeding method and exam-oriented education, which limits the students' thinking ability. A descriptive study carried out by Selen \& Filiz (2015) revealed that $90.6 \%$ of students were found to be in the lower critical thinking level. Song et al., (2014) confirmed that failure to apply knowledge and mental - motor skills from academic to clinical practice implied a low critical thinking ability among nursing students although they were introduced to critical thinking. According to Hong \& Yu (2017), students who adopted case-based learning (CBL) achieved 15.43 points $(5.35 \%)$ higher than the control group.
In a study by Selen \& Filiz (2015), the level of critical thinking was not at the desired level due to factors such as genetic influences, family background, education level and age. They found that there are no significant differences between gender and critical thinking scores whereas the educational level was found to be statistically significant. Students who read 6-20 books per year have a higher score as compared to the ones who do not read any books. According to Gunaydin \& Barlas (2015), increase in age and professional knowledge level can significantly affect critical thinking disposition level, but not the academic achievement of nursing students. In an academic performance, critical thinking level has significant correlation to academic performance and success of a nursing student (Pitt et al., 2015).

Hence the aim of this study is to determine the level of critical thinking ability among the nursing students and the differences in the level of critical thinking ability according to the sociodemographic variables.

\section{METHODOLOGY}

\section{Study Design, Setting and Sample}

This cross-sectional survey design was conducted among second and third year Diploma in Nursing students who were actively studying in two selected nursing colleges. The Raosoft Sample Size Calculator (Raosoft, 2004) was used to gain an appropriate sample size based on the study setting's total student population $(n=200)$. This process resulted in an estimated sample size of 158 , which gave a confidence level of $95 \%$ with a $5 \%$ error margin including $10 \%$ for attrition rate. Students who were in Year 1 of the Diploma in Nursing programme were excluded as they lack clinical exposure and knowledge which will affect the critical thinking ability.

\section{Ethical Consideration}

Ethical approval was obtained from the ethical committee of the university, Principals from both nursing colleges, original author of the instrument and participants. Participant anonymity and confidentiality were guaranteed. Participants received information about the study and what would be required of them if they chose to take part. Information included participants' right to withdraw from the study at any time.

\section{Measurement and Instrument}

The questionnaire consists of two sections. Section 1 contains the demographic data, which include age, 
gender, pre-university qualification, working experience and level of study in programme. Section 2 comprise of a 20-item Critical Thinking Ability Scale for College Students (Park, 1999) with a 5-point Likert type scale. The instrument has four sub-scales which include intellectual curiosity, eagerness and healthy scepticism (7 items), intellectual honesty (6 items), prudence (4 items), and objectivity ( 3 items). The total score ranges from 20-100 whereby a higher score indicate a higher critical thinking ability.

Critical thinking ability was conceptualised by four subscales. Intellectual, Eagerness and Health Scepticism refers to the habit of always seeking the best possible understanding of any given situation and the curiosity and eagerness to obtain more knowledge. Intellectual honesty measures the open mindedness and humbleness of a person to accept other's comments, idea and willingness to be corrected. Prudence measures cautiousorientation, organisational skills and reliability while objectivity refers to independent reasoning based on reality and impartial inquiry without being influenced by subjective judgement.

\section{Validity and Reliability Testing}

The reliability of the instrument for this study was tested by a pilot study conducted on 30 students to rule out any ambiguity in the questionnaires. The content validity was ascertained by the expert panel comprising of two principals of the colleges. Both agreed that the content was valid, and no amendments required. Reliability of the items in the instrument was determined by Cronbach's Alpha Reliability Coefficient value which yielded the value of 0.74 .

\section{Data analysis}

Data collected were analysed using Statistical Package for the Social Sciences (SPSS) 23.0. Frequency and percentage were used to analyse the demographic data while mean score and standard deviation were calculated to analyse the students critical thinking ability. The mean scores of critical thinking ability between the two groups were compared using the $t$-test method. Alpha was established at 0.05 for each statistical analysis.

\section{RESULTS}

\section{Demographic characteristics}

A total of 200 nursing students (100\% response rate) participated in the study with age ranging from 18 to 29 years old $(M=20.37 ; S D=1.39)$. Females $(n=174 ; 87 \%)$, Chinese $(\mathrm{n}=98 ; 49 \%)$, SPM qualification $(\mathrm{n}=169$; $84.5 \%$ ) and those who did not have any working experience in healthcare setting $(n=117,58.5 \%)$ constituted the largest portion of the sample population (Refer Table 1).

Table 1: Demographic Data of Participants (n=200)

\begin{tabular}{|l|l|r|l|l|}
\hline \multicolumn{1}{|c}{ Variables } & \multicolumn{1}{c}{ Categories } & \multicolumn{2}{c|}{ Frequency (\%) } & \multicolumn{1}{c|}{ M SD } \\
\hline \multirow{2}{*}{ Age (Years) } & $\leq 20$ & 133 & $(66.5 \%)$ & $20.37 \pm 1.39$ \\
\cline { 2 - 5 } & $>20$ & 67 & $(33.5 \%)$ & \\
\hline \multirow{2}{*}{ Gender } & Male & 26 & $(13.0 \%)$ & \\
\cline { 2 - 5 } & Female & 174 & $(87.0 \%)$ & \\
\hline \multirow{2}{*}{ Ethnicity } & Chinese & 98 & $(49.0 \%)$ & \\
\cline { 2 - 5 } & Non- Chinese & 102 & $(51.0 \%)$ & \\
\hline $\begin{array}{l}\text { Pre_college } \\
\text { Education }\end{array}$ & SPM & 169 & $(84.5 \%)$ & \\
\cline { 2 - 5 } $\begin{array}{l}\text { Level of Study in } \\
\text { Program }\end{array}$ & Pre-University & 31 & $(15.5 \%)$ & \\
\hline \multirow{2}{*}{$\begin{array}{l}\text { Pre_experience at } \\
\text { Hospital or Health } \\
\text { Agency }\end{array}$} & Second Year & 111 & $(55.4 \%)$ & \\
\cline { 2 - 5 } & Third Year & 89 & $(44.5 \%)$ & \\
\hline College & No & 83 & $(41.5 \%)$ & \\
\cline { 2 - 5 } & College A & 117 & $(58.5 \%)$ & \\
\cline { 2 - 5 } & College B & 100 & $(50.0 \%)$ & \\
\hline
\end{tabular}

\section{Level of Critical Thinking Ability}

The total scores of critical thinking ability are presented in Table 2. When the critical thinking scores of the students were considered, the mean overall score of the students was $3.63(\mathrm{SD}=0.50)$ out of the 5-Likert scale. Among the 20 items, item 10 showed the highest mean of $4.37(\mathrm{SD}=0.73)$. This indicates that participants listen and pay attention to what the others say in a discussion. This is followed by item "I enjoy intellectual discussions" with a mean of 4.10 $(\mathrm{SD}=0.73)$. The third highest mean score was 4.10 $(\mathrm{SD}=0.70)$ by item 11 . Respondents mostly accept ideas or statement that contradicts with their own as long as there is sufficient evidence to support them. On the other hand, most respondent disagreed that they tend to think carelessly and make hasty decisions $(\mathrm{M}=2.42 ; \mathrm{SD}=1.11)$. The second lowest was item 20 with mean of 2.49 ( $\mathrm{SD}=0.91)$ "I tend to fall into difficult situations due to my overly subjective judgements or decisions." The third lowest mean was $2.60(\mathrm{SD}=0.89)$ where respondents perceived that they do think objectively when discussing about something that is directly related to themselves (Table 2). 
Table 2: Mean Scores of Critical Thinking Ability According to Descending Order $(n=200)$

\begin{tabular}{|c|c|c|}
\hline No & Item & $\mathbf{M} \pm \mathbf{S D}$ \\
\hline Q10. & $\begin{array}{l}\text { I listen and pay atten tion to what the others say in a } \\
\text { discussion }\end{array}$ & $4.37 \pm 0.73$ \\
\hline Q4. & I enjoy intellectual discussions & $4.10 \pm 0.73$ \\
\hline Q11. & $\begin{array}{l}\text { I accept ideas or statement that contradicts with my own } \\
\text { as long as there are sufficient sources supporting it }\end{array}$ & $4.10 \pm 0.70$ \\
\hline Q15. & $\begin{array}{l}\text { I review anything that is related to a statement or } \\
\text { opinion from various perspectives before judging it }\end{array}$ & $4.09 \pm 0.74$ \\
\hline Q14. & $\begin{array}{l}\text { I analyse and review all the information thoroughly } \\
\text { before coming out with a judgement or decision }\end{array}$ & $4.06 \pm 0.74$ \\
\hline Q1. & I prefer to discuss a topic with other people & $4.05 \pm 0.76$ \\
\hline Q2. & I actively participate in a discussion & $3.90 \pm 0.80$ \\
\hline Q16. & $\begin{array}{l}\text { I reserve any judgement before appropriate and } \\
\text { sufficient sources are secured }\end{array}$ & $3.87 \pm 0.79$ \\
\hline Q12. & $\begin{array}{l}\text { I accept that it is possible for ideas that I strongly claim } \\
\text { in a discussion to have errors }\end{array}$ & $3.79 \pm 0.73$ \\
\hline Q8. & I accept any criticism regarding my own ideas & $3.64 \pm 0.74$ \\
\hline Q7. & $\begin{array}{l}\text { I do not think it is difficult to solve something } \\
\text { complicated }\end{array}$ & $3.59 \pm 0.86$ \\
\hline Q5. & $\begin{array}{l}\text { I will raise my questions about something even if it is } \\
\text { something widely accepted and believed }\end{array}$ & $3.48 \pm 0.91$ \\
\hline Q6. & $\begin{array}{l}\text { I have doubts about many things that are already } \\
\text { generallyaccepted. }\end{array}$ & $3.46 \pm 0.85$ \\
\hline Q13. & $\begin{array}{l}\text { It is di fficult for me to understand people who have } \\
\text { opposing values or ideology as mine }\end{array}$ & $3.13 \pm 1.02$ \\
\hline Q19. & $\begin{array}{l}\text { I tend to include my own subjective judgement and } \\
\text { stereotype when discussing or making decisions }\end{array}$ & $2.94 \pm 2.80$ \\
\hline Q3. & I tend to simply go over a discussion & $2.80 \pm 0.90$ \\
\hline Q9. & I do not try to accept ideas that are opposite my own & $2.77 \pm 0.92$ \\
\hline Q18. & $\begin{array}{l}\text { When discussing about something that is directly } \\
\text { related to myself, I fail to think objectively }\end{array}$ & $2.60 \pm 0.89$ \\
\hline Q20. & $\begin{array}{l}\text { I tend to fall into difficult situations due to my overly } \\
\text { subjectivejudgements or decisions }\end{array}$ & $2.49 \pm 0.91$ \\
\hline Q17. & I tend to think carelessly and make hasty decisions & $2.42 \pm 1.11$ \\
\hline \multicolumn{2}{|r|}{ Mean Total Score } & $3.63 \pm 0.50$ \\
\hline
\end{tabular}

\section{Intellectual, Eagerness and Health Skepticism Subscale}

Table 3 clearly shows the mean and standard deviation of items for intellectual, eagerness and health skepticism subscale. The mean total score for this intellectual, eagerness and health skepticism abilities are $3.63 \pm 0.50$. In this subscale, item 4 "I enjoy intellectual discussions" was rated the highest $(4.10 \pm 0.73)$ while item 3 "I tend to simply go over a discussion" was rated the lowest $(2.80 \pm 0.90)$. The total mean score was 3.63 $(\mathrm{SD}=0.50)$.
Table 3: Comparison of Mean Scores for the subscale of Intellectual, Eagerness and Health Skepticism $(n=200)$

\begin{tabular}{|c|c|c|}
\hline \multicolumn{2}{|r|}{ Item } & $\mathbf{M} \pm \mathbf{S D}$ \\
\hline Q4. & I enjoy intellectual discussions. & $4.10 \pm 0.73$ \\
\hline Q1. & $\begin{array}{l}\text { I prefer to discuss a topic with other } \\
\text { people. }\end{array}$ & $4.05 \pm 0.76$ \\
\hline Q2. & I actively participate in a discussion. & $3.90 \pm 0.80$ \\
\hline Q7. & $\begin{array}{l}\text { I do not think it is difficult to solve } \\
\text { something complicated. }\end{array}$ & $3.59 \pm 0.86$ \\
\hline Q5. & $\begin{array}{l}\text { I will raise my questions about something } \\
\text { even if it is something widely accepted and } \\
\text { believed. }\end{array}$ & $3.48 \pm 0.91$ \\
\hline Q6 & $\begin{array}{l}\text { I have doubts about many things that are } \\
\text { already generally accepted. }\end{array}$ & $3.46 \pm 0.85$ \\
\hline Q3. & I tend to simply go over a discussion. & $2.80 \pm 0.90$ \\
\hline & Mean of Total Scores & $3.63 \pm 0.50$ \\
\hline
\end{tabular}

Note: Range of critical thinking ability scale were from 1 (strongly disagree) to 5 (strongly agree)

\section{Intellectual Honesty Subscale}

Table 4 presents the mean and standard deviation of intellectual honesty. It has 6 items under this subscale. Item 10 showed the highest mean of $4.37(\mathrm{SD}=0.73)$ with the statement of "I listen and pay attention to what the others say in a discussion." followed by "I accept ideas or statement that contradicts with my own as long as there are sufficient sources supporting it." with the mean score $4.10(\mathrm{SD}=0.70)$. On the other hand, the lowest mean score was $2.77(\mathrm{SD}=0.92)$ whereby the respondent disagrees with the statement of "I do not try to accept ideas that are opposite my own." The total mean score of this subscale was $3.63(\mathrm{SD}=0.42)$.

Table 4: Comparison of Mean Scores for the subscale of Intellectual Honesty $(n=200)$

\begin{tabular}{|l|l|c|}
\hline \multicolumn{2}{|c|}{ Item } & M \pm SD \\
\hline Q10. & $\begin{array}{l}\text { I listen and pay attention to what the others } \\
\text { say in a discussion. }\end{array}$ & $4.37 \pm 0.73$ \\
\hline Q11. & $\begin{array}{l}\text { I accept ideas or statement that contradicts } \\
\text { with my }\end{array}$ & $4.10 \pm 0.70$ \\
\hline $\begin{array}{l}\text { own as long as there are sufficient sources } \\
\text { supporting it }\end{array}$ & $\begin{array}{l}\text { I accept that it is possible forideas that I } \\
\text { strongly claim in a discussion to have errors. }\end{array}$ & $3.79 \pm 0.73$ \\
\hline Q12. & $\begin{array}{l}\text { I accept any criticism regarding my own } \\
\text { ideas. }\end{array}$ & $3.64 \pm 0.74$ \\
\hline Q8. & $\begin{array}{l}\text { It is difficult for me to understand people } \\
\text { who have opposing values or ideology as } \\
\text { mine. }\end{array}$ & $3.13 \pm 1.02$ \\
\hline Q9 & $\begin{array}{l}\text { I do not try to accept ideas that are opposite } \\
\text { my own. }\end{array}$ & $2.77 \pm 0.92$ \\
\hline & \multicolumn{1}{c|}{ Mean of Total Scores } & $\mathbf{3 . 6 3} \pm \mathbf{0 . 4 2}$ \\
\hline
\end{tabular}

Note. Range of critical thinking ability scale were from 1 (strongly disagree) to 5 (strongly agree) 


\section{Prudence Subscale}

Table 5 presents the means and standard deviations of prudence. It consists of 4 items under this subscale. Item 15 showed the highest mean of $4.09(\mathrm{SD}=0.74)$ with the statement of "I review anything that is related to a statement or opinion from various perspectives before judging it." followed by "I analyse and review all the information thoroughly before coming out with a judgment or decision." with the mean score of $4.06(\mathrm{SD}=0.74)$. On the other hand, the lowest mean score was item 17 with the mean score of $2.42(\mathrm{SD}=1.11)$. The respondents disagreed that they tend to think carelessly and make hasty decisions. The total mean score was $3.61(\mathrm{SD}=0.41)$.

Table 5: Comparison of Mean Scores for the subscale of Prudence $(n=200)$

\begin{tabular}{|c|c|c|}
\hline \multicolumn{2}{|r|}{ Item } & $\mathbf{M} \pm$ SD \\
\hline Q15 & $\begin{array}{l}\text { I review anything that is related to a statement or } \\
\text { opinion from various perspectives before judging it }\end{array}$ & $4.09 \pm 0.74$ \\
\hline Q14 & $\begin{array}{l}\text { I analyse and review all the information thoroughly } \\
\text { before coming out with a judgement or decision }\end{array}$ & $4.06 \pm 0.74$ \\
\hline Q16 & $\begin{array}{l}\text { I reserve any judgement before appropriate and } \\
\text { sufficient sources are secured }\end{array}$ & $3.87 \pm 0.79$ \\
\hline Q17. & I tend to think carelessly and make hasty decisions & $2.42 \pm 1.11$ \\
\hline & Mean of Total Scores & $3.61 \pm 0.41$ \\
\hline
\end{tabular}

Note: Range of critical thinking ability scale were from 1 (strongly disagree) to 5 (strongly agree)

\section{Objectivity Subscale}

As shown in Table 6, item 19 has the highest mean score of $2.94(\mathrm{SD}=2.80)$. Respondents tend to include their own subjective judgement and stereotype when discussing or making decisions. The second highest was item 18 "When discussing about something that is directly related to myself, I fail to think objectively." with mean score of 2.60 ( $\mathrm{SD}=0.89)$. Respondents disagreed that they tend to fall into difficult situations due to overly subjective judgements or decisions and rated this the lowest $(\mathrm{M}=2.49 ; \mathrm{SD}=0.91)$. The total of mean score for this subscale was $2.68(\mathrm{SD}=0.64)$.

Table 6: Comparison of Mean Scores for Critical Thinking subscales of Objectivity $(n=200)$

\begin{tabular}{|c|l|c|}
\hline \multicolumn{2}{|c|}{ Item } & M \pm SD \\
\hline Q19. & $\begin{array}{l}\text { I tend to include my own subjective judgement and } \\
\text { stereotype when discussing or making decisions }\end{array}$ & $2.94 \pm 2.80$ \\
\hline Q18. & $\begin{array}{l}\text { When discussing about something that is directly } \\
\text { related to myself, I fail to think objectively }\end{array}$ & $2.60 \pm 0.89$ \\
\hline Q20. & $\begin{array}{l}\text { I tend to fall into difficult situations due to my } \\
\text { overly subjective judgements or decisions }\end{array}$ & $2.49 \pm 0.91$ \\
\hline & \multicolumn{2}{|c|}{ Mean of Total Scores } \\
\hline
\end{tabular}

Note. Range of critical thinking ability scale were from 1 (strongly disagree) to 5 (strongly agree)
Comparison of Mean Scores of Subscales for Critical Thinking Ability

Comparison of the four subscales showed that the subscale Intellectual, Eagerness and Health Scepticism scored the highest mean score $(\mathrm{M}=3.63 ; \mathrm{SD}=0.50)$ followed by Intellectual Honesty $(\mathrm{M}=3.63 \mathrm{SD}=0.42)$. The lowest subscale was objectivity with a mean score of 2.68 ( $\mathrm{SD}=0.64)$ (Refer Table 7).

Table 7: Comparison of Mean Scores for Critical Thinking Ability Subscales $(\mathrm{n}=200)$

\begin{tabular}{|c|c|}
\hline Critical Thinking Ability Subscales & $\mathbf{M} \pm \mathbf{S D}$ \\
\hline Intellectual, Eagerness and Health Scepticism & $3.63 \pm 0.50$ \\
\hline Intellectual Honesty & $3.63 \pm 0.42$ \\
\hline Prudence & $3.61 \pm 0.41$ \\
\hline Objectivity & $2.68 \pm 0.64$ \\
\hline Mean of Overall Scores & $3.63 \pm 0.50$ \\
\hline
\end{tabular}

Note. Range of critical thinking ability scale were from 1 (strongly disagree) to 5 (strongly agree

Differences between demographic variables and the critical thinking ability level

The mean and standard deviation of critical thinking total scores for age group was 20.37 $(\mathrm{SD}=1.39)$. No significant differences in critical thinking ability were noted between these two age groups $(t=-0.66 ; p$ value $=0.384)$. The total mean and standard deviation of critical thinking ability scores for male were $71.31(\mathrm{SD}=7.01)$ and female were 70.56 $(\mathrm{SD}=6.99)$. No significant difference of critical thinking ability scores was reported between the gender groups $(t=-0.51 ; p$ value $=0.877)$. Comparison of scores between Chinese $(\mathrm{M}=70.48 \mathrm{SD}=7.26)$ and non-Chinese $(\mathrm{M}=70.82 ; \mathrm{SD}=6.72)$ also showed no significant differences $(t=0.347, p$ value $=0.243)$. Similarly, those with SPM qualification $(M=70.76$; $\mathrm{SD}=7.17)$ and Pre - University qualification $(\mathrm{M}=70.06 ; \mathrm{SD}=5.86)$ also showed no significant differences $(t=0.511 ; p$ value $=0.205)$. Comparison of scores according to level of seniority and pre healthcare experiences also found no significant differences (ReferTable 7). 
Table 8: Association between demographic variables and level of critical thinking ability $(n=200)$

\begin{tabular}{|c|c|c|c|c|}
\hline Variables & Categories & $\begin{array}{l}\text { Mean Total Score } M \pm S D \\
\text { (Range } 20-100 \text { ) }\end{array}$ & $p$-value & $t$ \\
\hline \multirow[t]{2}{*}{ Age (Years) } & $\leq 20$ & $70.42 \pm 6.92$ & 0.38 & -0.66 \\
\hline & $>20$ & $71.12 \pm 7.12$ & & \\
\hline \multirow[t]{2}{*}{ Gender } & Male & $71.31 \pm 7.01$ & 0.87 & -0.51 \\
\hline & Female & $70.56 \pm 6.99$ & & \\
\hline \multirow[t]{2}{*}{ Ethnicity } & Chinese & $70.48 \pm 7.26$ & 0.24 & 0.34 \\
\hline & Non- Chinese & $70.82 \pm 6.72$ & & \\
\hline \multirow[t]{2}{*}{ Pre-college Education } & SPM & $70.76 \pm 7.17$ & 0.20 & 0.51 \\
\hline & Pre-University & $70.06 \pm 5.86$ & & \\
\hline \multirow{2}{*}{$\begin{array}{l}\text { Level of Study in } \\
\text { Program }\end{array}$} & Second Year & $70.54 \pm 7.06$ & 0.90 & -0.25 \\
\hline & Third Year & $70.80 \pm 6.91$ & & \\
\hline \multirow{2}{*}{$\begin{array}{l}\text { Pre-experience at } \\
\text { Hospital or Health } \\
\text { Agency }\end{array}$} & Yes & $70.52 \pm 7.19$ & 0.80 & -0.23 \\
\hline & No & $70.75 \pm 6.85$ & & \\
\hline
\end{tabular}

Note: $p$ - value $<0.05$ is considered to be significant

\section{DISCUSSION}

\section{Demographic Data}

The findings from this study illustrated that majority of the participants $(66.5 \%)$ were within the age group of $18-20$ with a mean age of $20.37 \pm 1.39$. The results were consistent with other studies which reported that mean age of participants were 20.9 years (Kim \& Choi, 2014), 20.5 years (Azizi-Fini et al., 2015) and 20.77 years (Moradi \& Taghadosi, 2016). This could be contributed to the minimum entry requirement for applicants into Nursing programme in the respective study sites. Respondents were mainly females $(87 \%)$ as compared to males $(13 \%)$. Similar findings were reported by Choi, Linquist \& Song (2014) and Gholami et al. (2016) which had $82.6 \%$ and $62.5 \%$ of female respectively in their nursing course. This implied that Nursing is still a female dominated profession especially in Asian countries. From the findings, respondents who participated were mainly non-Chinese. The education level was mainly at O-levels which is similar to Choi,
Linquist \& Song, (2014) and Abeer \& Sahar (2016). This could be due to the minimum entry requirement for Diploma in Nursing programmes. With regards to preexperience at hospital or health agency, $58.5 \%$ of the participants had no experience as compared to Abeer \& Sahar (2016) who had 58.3\% participants with experience at hospital or health agency before joining the programme.

\section{Level of Critical Thinking Ability}

The overall mean score for critical thinking ability was $3.63(\mathrm{SD}=0.50)$ in this study which was considered high as compared to the study by Kim \& Choi (2014) with a mean score of $3.39(\mathrm{SD}=0.33)$. Besides, Selen \& Filiz (2014) found out that the mean score of their study was $208.50(\mathrm{SD}=19.90)$ by using California Critical Thinking Disposition Inventory (CCTDI). According to a study by Hussein Ibrahim (2016), the mean total score for critical thinking was $287(\mathrm{SD}=2.1)$.

Findings of the present study showed that the 
highest mean score and standard deviation score of subscales was Intellectual, Eagerness, and Health Scepticism (3.63 \pm 0.50$)$ which is related to the habit of always seeking the best possible understanding of any given situation along with curiosity and eagerness to obtain more knowledge. In nursing practice, it is important that student nurses always have an attitude of curiosity and gain more knowledge. From this study, the student nurses signified that they enjoy intellectual discussion, which need to be encouraged further by the nursing faculty. In the clinical settings, this can be further enhanced through the support and encouragement of the nurse managers to involve student nurses in group discussions such as debriefing session, post critical event case study and clinical case presentations.

Therefore, active involvement of the ward nurses and managers in providing clinical preceptorship mentoring and support to nursing students will significantly reduce technical uncertainty, this included decision-making and resolution in nursing management. Inferior nursing performance students should be identified and be guided accordingly in the clinical practice. Continuous constructive feedback and liaise with nursing colleges is necessary for better improved nursing student training. Such continuous behaviour among the student nurses, will improve the patient care, patient satisfaction. In this manner they will become efficient in dealing difficult situations, with reduction in clinical errors.

Findings of the present study showed that intellectual honesty was rated as the highest subscale $(3.63 \pm 0.42)$. Similar findings were reported by Kim \& Choi (2014). Self-confidence and inquisitiveness were the highest rated subscale while truth-seeking and maturity was rated as the lowest subscale Aber \& Saher (2014). Similar findings were reported by Shin et al., (2006) where self-confidence and inquisitiveness were rated the highest subscale while analytical skill being the lowest.

As for prudence, the mean score and standard deviation obtained was $3.61 \pm 0.41$. Prudence measures cautious-orientation, organizational skills and reliability. A higher prudence score indicates higher farsightedness. Low risk minded along with meticulous behaviour that justifies risk and benefits before the actions, may contributes in personal assertiveness, productivity, insights and progressively leading towards goals. To make a significant distinction, prudence is very important item in nursing professional in making clinical decisions and to embark nursing journey that delve in department of nursing practice along with research and management. In contrast, hypothesis for this can be explained by the fact that the use of wisdom to balance the prudence skill without overuse, might eventually prevent unrewarded and resentment situations. Kim \& Choi (2014) using Park instrument reported that prudence had a mean and standard deviation of $3.44 \pm 0.56$ and was one of the high variables $(r=0.458$, $p<0.001)$ in critical thinking disposition that crucially impact on problem solving ability.

The objectivity results from this study revealed a mean and standard deviation of $2.68 \pm 0.64$. They understood that they should not make any careless, nasty, overly subjective decisions or judgment. This implied that the nurses are aware that they should not make subjective decisions when encountering any difficult situation. Objectivity refers to independent reasoning based on reality and impartial inquiry without being influenced by subjective judgement. Cultivation of objectivity characteristic in critical thinking assist nurses to identify bias in major or minor scientific research, operational processes and misguided practices (Howes, 2015). Such important intellectual objectivity aptly craft nurses to align with the organization policies, enable them to address ethical dilemma issues in wellness, maintenance and eliminate/inhibit certain performance at clinical practices. The low scores were consistent with findings by Kim \& Choi (2014) and Hussein Ibrahim (2016), where objectivity score was $2.68 \pm 0.64$ and $33.2 \pm 0.4$ respectively due to reluctance to re-assess new knowledge. The truth- seeking result is consistent with Wang et al., (2018) where low scores $(3.73 \pm 0.57)$ were also reported as compared with medical students. It was said to be related to individual confidencelevel.

\section{Differences between demographic variables and the critical thinking ability level}

No significant differences between demographic variables and critical thinking ability level were reported in this study. Kim \& Choi (2014) also reported similar findings. However, Selen \& Filiz (2015) concluded that maternal education status was related to critical thinking ability while Aber \& Sahar (2016) reported a significant difference according to semester and nationality. A study by Kim et al., (2006) showed a significant difference in the scores according to academic years. This was also reported by Song et al., (2014) where fourth-year students had the highest scores $(72.96 \pm 8.64)$ while third- 
year students had the lowest scores $(62.35 \pm 8.09)$, which indicated a significant difference in the scores of the three groups $(\mathrm{F}=26.79 ; P<0.05)$. Furthermore, Gunaydin \& Barlas (2015) also reported that age, semester level, economic status and father's occupation showed significant differences with critical thinking ability.

\section{Limitations}

This study had several limitations that required considerations in future study, namely the generalizability and study design. Only two nursing colleges were included which might not represent the situation at other nursing colleges. Future research should also be extended to public nursing colleges using a randomized sampling method. In addition to that that a comparison of critical thinking ability among students in colleges using other mode of delivery such as problem-based learning as compared to didactic mode is also suggested.

\section{CONCLUSION}

In view of the importance of critical thinking in nursing practice, didactic teaching methods need to be reviewed in order to revolutionize nursing education and eventually develop the critical thinking ability amongst nursing students. In addition to that with the current shortage of nurses, the ability to think critically is a necessity for the young nurses to manage the ward and ensure that patients are safe under their care. The way forward requires academicians and clinicians to work together to ensure a transfer of knowledge and skills from the classroom to the clinical environment in order to develop and enhance the ability to think critically in making clinical decision and produce thinking nurses for the future.

\section{Acknowledgement}

This study was conducted using the International Medical University research grant, (BN12018(PR-47). This study would not have been possible without the support from the principals and nursing students at each chosen nursing colleges. We would like to particularly thank the participants of this study without whom this study could not have been accomplished.

Abeer, R.K. \& Sahar, A.E.M.E. (2016). The correlation of critical thinking disposition and approaches to learning among baccalaureate nursing students. Journal of Education and Practice, 7(32), pp 91-103.

Aliakbari, F., Parvin, N., Heidari, M., \& Haghani, F. (2015). Learning theories application in nursing education. Journal of Education and Health Promotion, 4: 2.

Azizi-Fini, I., Hajibagheri, A. \& Adib-Hajbaghery, M. (2015). Critical thinking skills in nursing students: a comparison between freshmen and senior students. Nursing and Midwifery Studies, 4(1), e25721.

Choi, E., Linquist, R. \& Song, Y., (2014). Effects of problem-based learning vs. traditional lecture on Korean nursing students' critical thinking, problem-solving, and self-directed learning. Nurse Education Today, 34(1), pp52-56.

Da Silva, B.A. \& Krishnamurthy, M. (2016). The alarming reality of medication error: a patient case and review of Pennsylvania and National data. Journal of Community Hospital Internal Medicine Perspectives, 6(4).

Gholami, M., Moghadam, P.K., Mohammadipoor, F., Tarahi, M.J., Sak, M., Toulabi, T. \& Pour, A.H. (2016). Comparing the effects of problem-based learning and the traditional lecture method on critical thinking skills and metacognitive awareness in nursing students in a critical care nursing course. Nurses Education Today, 45, pp 16-21.

Gunaydin, N. \& Barlas, G.U. (2015). Determination the critical thinking and empathy disposition of nursing students. Middle Black Sea Journal of Health Science, 1(3), pages 1-8.

Hong, S. \& Yu, P. (2017). Comparison of the effectiveness of two styles of case-based learning implemented in lectures for developing nursing students critical thinking ability: A randomized controlled trial. International Journal Nursing Study, 68, pp 16-24.

Howes, M. (2015). Objectivity, intellectual virtue, and community, in F. Padovani, A. Richardson \& J. Y. Tsou (eds.), Objectivity in science, Dordrecht, Springer, pp 173-188.

Hunter, S., Pitt, V., Croce, N. \& Roche, J. (2014). Critical Thinking Skills of Undergraduate Nursing Students: 
Description and Demographic Predictors. Nurses Education Today, 34(5), pp 809-814.

Hussein Ibrahim, R. (2016). Critical thinking dispositions among students of Mosul's Nursing College. The Malaysian Journal of Nursing, 7(2), pp 3-7.

Jackson, Y.M. (2016). An exploration of the effectiveness of problem-based learning in nursing education. Minnesota: Walden University, Dissertations and Doctoral Studies.

Kim, K.S. \& Choi, J.H. (2014). The relationship between problem solving ability, professional self-concept and critical thinking disposition of nursing students. International Journal of Bio-Science and Bio-Technology, 6(5), pp 131-142.

Ministry of Higher Education Malaysia (2010). Development of nursing education in Malaysia towards the year 2020. Shah Alam, Malaysia: University Publication Centre.

Moradi, T. \& Taghadosi, M. (2016). The effect of problem-based learning clinical education on nursing standard's critical thinking. Future of Medical Education Journal, 6(3), pp 20-25.

Ng, Y.M. (2015). Critical thinking skills among trained nurses on patient diabetic care management: A case study (Doctor of Philosophy thesis, USM, Penang, Malaysia).

Park, S.H. (1999). The effects of the program for the improvement of college students' critical thinking ability. Journal of Educational Psychology, 13(4), pp 93-112.

Pitt, V., Powis, D., Levett-Jones, T. \& Hunter, S. (2015). The influence of critical thinking skills on performance and progression in a preregistration nursing program. Nursing Education Today, 35(1), pp 125-31.

Raosoft (2004). Sample Size Calculation. Retrieved from http://www.raosoft.com/samplesize.html

Rezaeil, R., Saatsaz, S., Sharif, H.N., Moulookzadeh, S. \& Behedhti, Z. (2015). Anxiety and Critical Thinking Skills in Nursing Students. British Journal of Education, Society \& Behavioural Science, 10(2), pp 1-7.

Selen. O.A. \& Filiz, S. (2015). Nursing Student's Critical Thinking Levels. The European Proceedings of Social \& Behavioural Sciences, pp 74-82.

Shin, K.R., Lee, J.H., Ha, J.Y. \& Kim, K.H. (2006). Critical thinking dispositions in baccalaureate nursing students. Journal of Advance Nursing, 56(2), pp 182-189.

Song, J.Y, Zhu, X.L., Liu, C.P., Miao, X.X. Lin, X.Z., Guo, H.L. \& Tang, C. (2014). Comparison of clinical thinking ability in nursing students of different grades. Chinese Nursing Research, 1, pages 1-4.

Wang, X.X., Sun, X.X., Huang, T.H., He, R.Q., Hao, W.N. \& Zhang, L. (2018). Development and validation of critical thinking disposition inventory for Chinese medical college students. BMC Medical Education, 19(1), 200. 